\title{
STUDI TERHADAP PEMBAGIAN DIVIDEN DAN DAMPAKNYA TERHADAP HARGA SAHAM PERUSAHAAN-PERUSAHAAN YANG TERDAFTAR DI BURSA EFEK INDONESIA PERIODE 2011-2014
}

\author{
Retno M.E.L \\ Dosen Tetap Fakultas Ekonomi Universitas Pakuan \\ Putri Permatasari \\ Mahasiswa Fakultas Ekonomi Universitas Pakuan
}

\begin{abstract}
ABSTRAK
Tujuan dari penelitian ini adalah untuk menjelaskan apakah ada peranan pola pembagian dividen dalam mempengaruhi harga saham. Metode pengolahan data yang digunakan adalah dengan analisis deskriptif dan komparatif. Hasil penelitian ini menunjukkan bahwa tidak semua emiten yang terdaftar di BEI membagikan dividen dan pembagian dividennya pun bervariasi. Dari 285 emiten ada 13 emiten yang membagikan dividen diatas Rp500 per lembarnya dan emiten yang paling besar membagikan dividen yaitu (MLBI). Emiten yang rutin membagikan dividen dari 2011-2014 yaitu sebanyak 122 emiten, dengan emiten yang memiliki rata-rata dividend yield dan standar deviasi terbesar yaitu SQBB dan yang paling kecil yaitu SMMA. Dari 122 emiten yang membagikan dividen secara rutin, emiten yang memiliki risiko relatif (covariance) paling rendah yaitu ASDM. Setelah dibandingkan dengan harga saham, emiten yang memiliki korelasi positif antara pembagian dividen dan harga saham lebih besar yaitu $75,41 \%$. Dari penelitian ini dapat disimpulkan teori yang mengatakan bahwa pembagian dividen akan mempengaruhi harga saham tidak dapat digeneralisasikan. Pembagian dividen tidak selalu mempengaruhi dalam pergerakan harga saham dikarenakan masih adanya emiten yang pembagian dividennya berkorelasi negatif dengan harga saham. Dalam berinvestasi saham para investor tidak perlu berpatokan kepada pembagian dividen, karena tidak semua emiten yang membagikan dividen berkorelasi positif terhadap harga saham.
\end{abstract}

Kata kunci: dividen, harga saham, emiten dan BEI

\begin{abstract}
The purpose of this study was to elucidate whether there is a role in influencing patterns of distribution of dividend stock prices. Data processing methods used were descriptive and comparative analysis. The results of this study indicate that not all issuers listed on the Stock Exchange dividends and the distribution of the dividend were varied. Of the 285 listed companies there are 13 issuers that pay dividends above Rp500 per share and most large issuers that pay dividends (MLBI). Issuers who regularly distribute dividends from 2011-2014 as many as 122 listed companies, with issuers who have an average dividend yield and the standard deviation is $S Q B B$ largest and the smallest is the SMMA. Of the 122 listed companies that distribute dividends on a regular basis, issuers that have a relative risk (covariance) is lowest that ASDM. After compared with stock prices, issuers that have a positive correlation between the distribution of dividends and stock prices is larger, ie $75.41 \%$. From this study we can conclude that the theory says that the dividend distribution will affect the stock price can not be generalized. The dividend distribution does not necessarily affect the movement of the stock price still due to the dividend distribution of listed companies is negatively correlated with stock prices. In investing stock investors need not sticking to the distribution of dividends, since not all issuers that pay dividends positively correlated to the stock price.
\end{abstract}

Keywords: dividend, stock price, listed on the Stock Exchange

JIAFE (Jurnal Ilmiah Akuntansi Fakultas Ekonomi)

Volume 2 No. 1 Tahun 2016 Edisi 2, Hal. 69-85 


\section{Pendahuluan}

Pasar modal merupakan tempat yang menarik untuk berinvestasi. Saat ini pasar modal Indonesia telah mengalami perkembangan yang pesat dan memiliki peranan penting dalam menghimpun dana dari masyarakat yang ingin berinvestasi. Pasar modal di Indonesia yaitu Bursa Efek Indonesia (BEI). BEI merupakan tempat untuk membeli obligasi dan saham. Di BEI, harga-harga saham mengalami fluktuasi baik berupa kenaikan maupun penurunan. Pembentukan harga saham terjadi karena adanya permintaan dan penawaran atas saham tersebut. Dengan kata lain harga saham terbentuk oleh supply dan demand atas saham tersebut. Supply dan demand tersebut terjadi karena adanya banyak faktor, baik yang sifatnya spesifik atas saham tersebut (kinerja perusahaan dan industri dimana perusahaan tersebut bergerak) maupun faktor lain seperti tingkat suku bunga, inflasi, nilai tukar dan faktor-faktor non ekonomi seperti kondisi sosial dan politik, dan faktor lainnya.

Walaupun jumlah transaksi saham pada tahun 2014 meningkat secara signifikan yaitu $37,22 \%$ dari 37,499,462 kali pada tahun 2013 menjadi 51,457,606 kali pada tahun 2014, namun volume dan nilai transaksinya mengalami penurunan. Volume saham yang diperdagangkan menurun $1,16 \%$ dari $1,342,657$ pada tahun 2013 menjadi 1,327,016 pada tahun 2014. Total nilai saham yang diperdagangkan menurun $4,52 \%$ dari $\mathrm{Rp}$ 1,522,122 juta pada tahun 2013 menjadi Rp 1,453,392 juta pada tahun 2014. Berikut transaksi saham yang ada di Bursa Efek Indonesia :

Tabel 1

Pergerakan Harga Saham

\begin{tabular}{|l|c|c|c|}
\hline Transaksi Saham & 2013 & 2014 & Kenaikan \\
\hline Volume (juta lembar) & $1,342,657$ & $1,327,016$ & $-1,16 \%$ \\
\hline Nilai (Rp miliar) & $1,522,122$ & $1,453,392$ & $-4,52 \%$ \\
\hline Frekuensi (x) & $37,499,462$ & $51,457,606$ & $37,22 \%$ \\
\hline IHSG & $4.274,18$ & $5.266,98$ & $23,23 \%$ \\
\hline
\end{tabular}

Sumber :www.idx.co.id

Bila dilihat dari Tabel 1, Indeks Harga Saham Gabungan tahun 2014 mengalami kenaikan sebesar 23,23\% dari 4.274,18 pada tahun 2013 menjadi 4.274,98 pada tahun 2014. Hal ini menunjukan bahwa selama tahun 2014, BEI mampu memberikan capital gain sebesar $23,23 \%$.

Selain capital gain, investasi saham memiliki potensi pendapatan dari dividen yang dibagikan oleh emiten. Dividen itu sendiri yaitu menurut Tjiptono Darmadji dan Hendy $M$. Fakhruddin (2010:140) dividen adalah pembagian sisa laba bersih perusahaan yang didistribusikan kepada pemegang saham atas persetujuan RUPS. Pada tahun 2014 jumlah perusahaaan yang membagi dividen mengalami kenaikan yaitu dari 161 atau $33,33 \%$ dari total perusahaan yang terdaftar di BEI menjadi 234 perusahaan atau 46,25\%. Jumlah emiten yang membagi dividen pada tahun 2014 mengalami kenaikan sebesar 45,34\%. Range dividen yang dibagikan pada tahun 2014 juga semakin lebar dari tahun sebelumnya, yaitu antara Rp 1 - Rp14.566 pada tahun 2013, menjadi Rp0,32 menjadi Rp46.076, sebagaimana disajikan pada tabel di bawah: 
Tabel 2

Daftar Perusahaan yang Membagikan Dividen

\begin{tabular}{|l|c|c|}
\hline Tahun & 2013 & 2014 \\
\hline Jumlah Emiten Pembagi Dividen & 161 & 234 \\
\hline Range Dividen Tunai (Rp) & $1-14.566$ & $0,32-46.076$ \\
\hline Jumlah Emiten & 483 & 506 \\
\hline Rasio Emiten Pembagi Dividen & $33,33 \%$ & $46,25 \%$ \\
\hline
\end{tabular}

Sumber : $\underline{w w w . i d x . c o . i d}$

Dari penelitan awal yang dilakukan penulis terdapat fenomena yang menarik antara lain:

1. Sebagian besar emiten BEI belum membagikan dividen dan harganya berfluktuasi baik mengalami kenaikan atau penurunan.

2. Jumlah dividen berubah secara acak

3. Terdapat dividen per lembar saham yang jumlahnya lebih besar dari harga pasar tahun sebelumnya

4. Variasi dan range dividen yang dibagikan sangat lebar.

Secara teoritis, perusahaan yang membagi dividen besar tentunya akan meningkatkan harga saham dan tentunya akan menghasilkan capital gain yang tinggi. Menurut Atmaja (2008:285), teori signaling merupakan suatu kenaikan dividen yang di atas biasanya merupakan suatu "sinyal" kepada para investor bahwa manajemen perusahaan meramalkan suatu penghasilan yang baik di masa mendatang. Sebaliknya, suatu penurunan dividen atau kenaikan di bawah kenaikan normal diyakini investor sebagai suatu sinyal bahwa perusahaan mengalami masa sulit di waktu mendatang. Kondisi yang tidak konsisten ini, mendorong penulis mengevaluasi apakah besaran pembagian dividen akan konsisten dengan perubahan harga saham sehingga investor akan bisa memprediksi harga saham di masa depan dan melihat capital gain.
Adapun tujuan yang hendak dicapai penulis dalam penelitian ini sebagai berikut:

1. Untuk mengetahui pola pembagian dividen perusahaan yang terdaftar di Bursa Efek Indonesia.

2. Untuk mengetahui kevariabilitasan dividen berdasarkan dividen yield.

3. Untuk konfirmasi korelasi pola pembagian dividen tunai apakah berpengaruh dalam pergerakan harga saham.

\section{Landasan Teori \\ 2.1. Kebijakan Dividen}

Dividen merupakan salah satu keputusan penting untuk memaksimumkan nilai perusahaan di samping keputusan investasi dan struktur modal (keputusan pemenuhan dana). Dividen merupakan distribusi laba kepada pemegang saham dalam bentuk aktiva atau saham perusahaan penerbit. Dividen yang dibagikan perusahaan dapat berupa dividen tunai, artinya kepada setiap pemegang saham diberikan dividen berupa tunai dalam jumlah rupiah tertentu untuk setiap saham atau dapat pula berupa dividen saham berarti kepada setiap pemegang saham diberikan dividen sejumlah saham sehingga jumlah saham yang dimiliki seorang pemodal akan bertambah dengan adanya pembagian dividen saham tersebut. Maka dapat disimpulkan bahwa dividen merupakan keuntungan yang dibagikan kepada para pemegang saham yang berasal dari laba bersih 
perusahaan.

Menurut Dyah Handayani BS $(2010,13)$ tujuan pembagian dividen adalah:

1. Untuk memaksimumkan kemakmuran bagi para pemegang saham. Hal ini karena sebagian investor menanamkan dananya di pasar modal untuk memperoleh dividen dan tingginya dividen yang dibayarkan akan mempengaruhi harga saham. Para investor percaya bahwa tingginya dividen yang dibayarkan berarti bahwa prospek perusahaan di masa yang akan datang bagus.

2. Untuk menunjukkan likuiditas perusahaan. Dengan dibayarkan dividen, diharapkan kinerja perusahaan di mata investor bagus. Sering kita jumpai bahwa sebagian perusahaan memberikan dividen dalam jumlah tetap untuk setiap periode. Hal ini dilakukan karena perusahaan ingin diakui oleh investor bahwa perusahaan yang bersangkutan mampu menghadapi gejolak ekonomi dan mampu memberikan hasil kepada investor.

3. Sebagian investor memandang bahwa resiko dividen lebih rendah dibanding resiko capital gain.

4. Untuk memenuhi kebutuhan para pemegang saham akan pendapatan tetap yang digunakan untuk keperluan konsumsi.

5. Dividen dapat digunakan sebagai alat komunikasi antara manajer dan pemegang saham. Informasi secara keseluruhan tentang kondisi intern perusahaan sering tidak diketahui oleh investor sehingga melalui dividen pertumbuhan perusahaan dan prospek perusahaan bisa diketahui.

Menurut Tjiptono Darmadji dan Hendy M. Fakhruddin (2010, 141) dividen dapat diberikan dalam berbagai bentuk. Dilihat dari bentuk dividen yang didistribusikan kepada pemegang saham, dividen dapat dibedakan menjadi beberapa jenis sebagai berikut:

1. Dividen tunai (cash dividend), yaitu dividen yang dibagi kepada pemegang saham dalam bentuk kas (tunai).

2. Dividen saham (stock dividend), yaitu dividen yang dibagi bukan dalam bentuk tunai melainkan dalam bentuk saham perusahaan tersebut.

3. Dividen property (property dividend), yaitu dividen yang dibagikan dalam bentuk aktiva lain selain kas atau saham, misalnya aktiva tetap dan surat-surat berharga.

4. Dividen likuidasi (liquidating dividend), yaitu dividen yang diberikan kepada pemegang saham sebagai akibat dilikuidasinya perusahaan. Dividen yang dibagikan adalah selisih nilai realisasi aset perusahaan dikurangi dengan semua kewajibannya.

Menurut James C. Van Horne dan John M. Wachowicz, Jr yang dialihbahasakan oleh Quratul'ain Mubarakah (2013, 206) kebijakan dividen adalah bagian yang tidak terpisahkan dalam keputusan pendanaan perusahaan. Kebijakan dividen merupakan cara pembagian dividen para pemegang saham yang dilakukan oleh suatu perusahaan. Menurut Kamaludin dan Rini Indriani $(2012,330)$ Kebijakan dividen adalah mencakup keputusan mengenai apakah laba akan dibagikan kepada pemegang saham atau akan ditahan untuk reinvestasi dalam perusahaan. Sangat sedikit perusahaan yang membayar dividen dalam jumlah yang sama dengan laba ditahan yang tersedia secara legal. Menurut Harjito (2012, 181) mengemukakan bahwa Kebijakan dividen merupakan bagian 
yang tidak dapat dipisahkan dengan struktur modal dan keputusan pendanaan perusahaan. Kebijakan dividen (dividend policy) merupakan keputusan apakah laba yang diperoleh perusahaan pada akhir tahun akan dibagi kepada pemegang saham dalam bentuk dividen atau akan ditahan untuk menambah modal guna membiayai investasi di masa yang akan datang. Dengan kata lain, kebijakan dividen merupakan suatu keputusan pihak manajemen yang menentukan apakah membayar return (perolehan) kepada pemegang saham atau mempertahankan return tersebut untuk diinvestasikan kembali di dalam perusahaan.

Maka dapat disimpulkan bahwa kebijakan dividen adalah keputusan atas laba yang di dapatkan perusahaan, apakah akan dibagikan dalam bentuk dividen atau ditahan untuk melakukan investasi di masa mendatang.

Menurut Kamaludin dan Rini Indriani (2012, 331) teori kebijakan dividen diantaranya sebagai berikut:

1. Kebijakan Dividen Relevan

a. Kebijakan Dividen

Pendekatan Walter

Menurut Walter pembayaran dividen akan optimal ditentukan dengan mengubah dividen (D) hingga harga saham per lembar di pasar menjadi maksimum. Model penentuan harga saham Walter yang akan optimal dengan kebijakan dividen tertentu adalah sebagai berikut:

$$
P=\frac{D+\frac{r}{\rho}(E-D)}{\rho}
$$

Di mana: $\mathrm{P}=$ harga pasar per lembar saham

$\mathrm{D}=$ DPS (dividend per share)

$\mathrm{E}=\mathrm{EPS}$ (earning per share)

$\mathrm{R}=\mathrm{ROI}$ (return on investment)

$\rho=$ tingkat kapitalisasi pasar

Walter mengemukakan rasio pembayaran dividen optimal ditentukan dengan mengubah D sampai dengan $P$ maksimum.

b. Bird in the Hand Theory (BIH)

Teori ini terinspirasi bahwa investor merasa lebih aman untuk memperoleh pendapatan pembayaran berupa dibandingkan menunggu capital gains yang belum pasti. Menurut Myrton Gordon dan John Linter bahwa biaya ekuitas $\left(k_{e}\right)$ akan turun apabila rasio pembayaran dividen dinaikkan, karena para investor kurang yakin terhadap capital gains dibandingkan seandainya menerima dividen yang lebih pasti.

c. Tax Preference Theory (TPT)

Dasar dari adanya teori ini yaitu bahwa bagi investor pendapatan yang relevan baginya adalah pendapatan bersih setelah pajak. Sehingga tingkat keuntungan yang diharapkan juga adalah pendapatan setelah pajak. Karena dividen dikenakan pajak, maka tentunya 
keuntungan akan lebih rendah sehingga investor lebih suka menahan laba mereka ke dalam perusahan.

2. Kebijakan Dividen Tidak Relevan Menurut MM rasio pembayaran (D) tidak akan mempengaruhi kekayaan pemegang saham. Nilai perusahaan hanya ditentukan oleh daya laba (earning power), atau kebijakan investasi. MM mengemukakan bahwa pengaruh pembayaran dividen terhadap kemakmuran pemegang saham akan diimbangi dengan jumlah yang sama dengan cara pembelanjaan atau pemenuhan dana yang lain.

Dalam situasi keputusan investasi given, maka apabila perusahaan membagikan dividen kepada pemegang saham, maka perusahaan harus mengeluarkan saham baru sebagai pengganti sejumlah pembayaran dividen tersebut. Dengan demikian kenaikan pendapatan dari pembayaran dividen akan diimbangi dengan penurunan harga saham sebagai akibat penjualan saham baru. Oleh sebab itu, jika dividen dibagi atau ditahan tidak mempengaruhi kemakmuran pemegang saham.

Menurut Kamaludin dan Rini Indriani (2012, 337) paling tidak ada enam pertimbangan manajerial dalam mengambil keputusan dividen. Pertimbangan-pertimbangan tersebut adalah:

1. Posisi likuiditas

Dividen merupakan arus kas keluar, maka semakin besar dividen yang dibayar maka akan memperkecil posisi likuiditas. Oleh sebab itu jika posisi likuiditas perusahaan sangat baik, maka semakin besar kemungkinan rasio pembayaran dividen. Perusahaan yang tingkat pertumbuhannya baik bisa jadi posisi likuiditas tidak baik, hal ini dimungkinkan karena dana perusahaan sebagian besar dialokasikan dalam aktiva tetap. Biasanya perusahaan akan mempertahankan posisi likuiditas, sehingga manajemen memutuskan tidak membayar dividen atau ditunda terlebih dahulu.

2. Alternatif pembiayaan lain

Alternatif pembayaran merupakan salah satu faktor yang dapat melindungi dari situasi yang tidak diinginkan. Apabila perusahaan dapat memperoleh alternatif pembiayaan dalam waktu yang relatif singkat, maka perusahaan dapat lebih leluasa memanfaatkan kas, termasuk untuk membayar dividen. Semakin mapan dan besar perusahaan biasanya akses pembiayaan akan lebih banyak dibandingkan dengan perusahaan kecil dan baru berdiri.

3. Perkiraan pendapatan

Perusahaan yang tumbuh dengan baik selama beberapa tahun, biasanya manajemen telah menetapkan perkiraan pendapatan yang tinggi pula. Apalagi prospek ekonomi masa yang akan datang akan lebih baik. Perusahaan seperti ini biasanya akan membayar dividen secara teratur dan stabil. Sebaliknya perusahaan yang perkiraan pendapatan tidak menentu, maka kebijakan dividennya lebih tidak menentu yang banyak menunggu situasi menjelang pembayaran dividen untuk diputuskan.

4. Kontrol kepemilikan

Dalam situasi kontrol kepemilikan agar saham tidak dikuasai oleh kelompok mayoritas manajemen dapat saja menetapkan dividen 
yang tinggi agar saham minoritas tidak jatuh pada kelompok tertentu, agar meyakinkan pemegang saham minoritas bahwa perusahaan berupaya memakmurkan para pemegang saham.

5. Inflasi

Dalam perekonomian dengan tingkat inflasi yang tinggi akan berdampak pada sumber-sumber pembiayaan. Artinya sumber pembiayaan sulit diperoleh, walaupun ada suku bunga sangat tinggi. Dalam situasi seperti ini, satu-satunya sumber pembiayaan yang biayanya relatif murah dengan menahan laba untuk tidak dibagi. Dalam situasi inflasi yang tinggi suatu perekonomian, biasanya akan memperkecil kemampuan perusahaan untuk membayar dividen, karena dana kas lebih banyak diinvestasikan kembali untuk membiayai perusahaan.

Dividend yield merupakan salah satu indicator untuk mengukur kebijakan dividen. Menurut Warsono (2003, 275) dividend yield adalah suatu ratio yang menghubungkan suatu dividen yang dibayar dengan harga saham biasa. Dividend yield secara matematis dapat diformulasikan sebagai berikut:

$$
\text { Dividend Yield }=\frac{\text { Dividen } \text { per lembar saham }}{\text { Harga per lembar saham }} \times 100 \%
$$

Dividend yield menyediakan suatu ukuran komponen pengembalian total yang dihasilkan dividen, dengan menambahkan apresiasi harga yang ada. Beberapa investor menggunakan dividend yield sebagai suatu ukuran risiko dan sebagai suatu penyaring investasi, yaitu mereka akan berusaha menginvestasikan dananya dalam saham yang menghasilkan dividend yield yang tinggi.

\subsection{Analisis Harga Saham}

Ada 2 pendekatan analisis pergerakan harga saham yang sering digunakan pelaku pasar di pasar modal, yaitu analisis teknikal dan analisis fundamental

1. Analisis Teknikal

Menurut Tjiptono Darmadji dan Hendy M. Fakhruddin (2012, 160) Analisis teknikal merupakan salah satu metode yang digunakan untuk penilaian saham, di mana dengan metode ini para analis melakukan evaluasi saham berbasis pada datadata statistik yang dihasilkan dari aktivitas perdagangan saham, seperti harga saham dan volume transaksi. Analisis Teknikal adalah teknik yang menganalisa fluktuasi harga saham dalam rentang waktu tertentu. Dari pergerakan tersebut akan terlihat pola tetentu yang dapat dipakai sebagai dasar untuk melakukan pembelian atau penjualan.

2. Analisis Fundamental

Menurut Saud Husnan (2009, 14), Analisis Fundamental adalah analisis yang mencoba memperkirakan harga saham yang akan datang dengan (i)mengestimasi nilai faktor-faktor fundamental yang mempengaruhi harga saham di masa yang akan datang (ii) menerapkan hubungan variabel-variabel tersebut sehingga diperoleh taksiran harga saham. Model ini sering disebut dengan share price forecasting model, dan sering dipergunakan dalam bberbagai pelatihan analisis sekuritas. 
Dalam membuat model peramalan harga saham tersebut, langkah yang penting adalah mengidentifikasikan faktor-faktor fundamental (seperti penjualan, pertumbuhan pejualan, biaya, kebijakan dividen, dan sebagainya) yang diperkirakan akan mempengaruhi harga saham. Setelah itu, bagaimana membuat suatu model dengan memasukkan faktorfaktor tersebut dalam analisis.

Sedangkan menurut Tjiptono Darmadji dan Hendy M. Fakhruddin (2012, 149) Analisis fundamental merupakan salah satu cara untuk melakukan penilaian saham dengan mempelajari atau mengamati berbagai indikator yang terkait dengan kondisi makro ekonomi dan kondisi industri suatu perusahaan hingga berbagai indikator keuangan dan manajemen perusahaan.

Dengan demikian, analisis fundamental merupakan analisis yang berbasis pada berbagai data riil untuk mengevaluasi atau memproyeksi nilai suatu saham. Beberapa data atau indikator yang umum digunakan antara lain: pendapatan, laba, pertumbuhan penjualan, imbal hasil atau pengembalian atas ekuitas (return on equity), margin laba (profit margin), dan data-data keuangan lainnya sebagai sarana untuk menilai kinerja perusahaan dan potensi pertumbuhan perusahaan di masa mendatang.

\subsection{Hubungan Pembayaran Dividen dengan Harga Saham}

Hubungan pembayaran dividen dengan harga saham dapat dijelaskan dari :

1. Teori tentang penilaian saham

Menurut Abdul Halim (2015,

4) bagi investor jumlah rupiah yang diterima dari pembayaran dividen risikonya lebih kecil dari capital gain (keuntungan menjual modal) dan dividen dapat diperkirakan sebelumnya. Sementara itu, capital gain lebih sulit diperkirakan sehingga pembayaran dividen tinggi dianggap bahwa perusahaan mempunyai prospek tingkat keuntungan yang baik. Sebaliknya, penurunan pembayaran dividen dianggap prospek tingkat keuntungan yang kurang baik sehingga harga saham cenderung mengikuti naik turunnya besaran dividen yang dibayarkan.

Pengaruh

penurunan besarnya dividen yang dibayar dapat menjadi informasi yang kurang baik bagi perusahaan karena dividen sebagai tanda tersedianya pendapatan perusahaan dan besarnya dividen yang dibayar sebagai informasi tingkat pertumbuhan pendapatan saat ini dan masa mendatang. Dengan anggapan tersebut, harga saham akan menjadi turun karena banyak pemegang saham yang akan menjual sahamnya. Dalam pendekatan ini, harga saham dapat diketahui dengan memperkirakan nilai saat ini dari proyeksi dividen yang akan diterima investor.

2. Kaitan diskonto arus kas dengan waktu pengumuman, pencatatan, dan pembayaran dividen

Dividen merupakan cashflow yang akan diterima oleh pemegang saham. Bila dikaitkan dengan diskonto arus kas yang nenurut James C. Van Horne dan John M. Wachowicz, Jr yang dialihbahasakan oleh Quratul'ain Mubarakah (2013, 21) Diskonto Arus Kas (discounted cash flow) yaitu metode evaluasi proyek investasi dan pemilihannya, yang menyesuaikan arus kas sepanjang waktu dengan nilai waktu dari 
uang. Metode diskonto arus kas $(D C F)$ dianggap dapat memberikan dasar yang lebih objektif untuk mengevaluasi dan memilih berbagai proyek investasi. Metode diskonto arus kas memungkinkan untuk menangkap berbagai perbedaan dalam waktu arus kas bagi berbagai proyek melalui proses diskonto. Perbedaan waktu dalam dividen menurut Kamaludin dan Rini Indriani (2012, 341) yaitu :

Tanggal pengumuman
dividen
Pengumuman pembagian dividen merupakan salah satu corporate action yang berasal dari intern emiten, yang juga merupakan salah satu faktor penting yang dapat mempengaruhi investor untuk berinvestasi. Di samping itu, pengumuman dividen juga mengandung informasi mengenai persepsi manajemen tentang prospek perusahaan di masa yang datang, yaitu jika dikaitkan dengan keuntungan yang diharapkan perusahaan serta aliran kas untuk membayar dividen. Informasi pengumuman perubahan dividen menyampaikan informasi berharga ke pasar karena dianggap mencerminkan ekspektasi manajemen tentang arus kas saat ini dan masa depan.

b. Tanggal pencatatan dividen Menunjukkan kapan buku transfer saham ditutup. Perusahaan mencatat seorang pemegang saham sebagai pemilik pada tanggal tertentu, dan berhak atas dividen. Contohnya, jika terjadi penjualan saham sampai jam sebelum ditutup bursa pada tanggal 11 Desember 2007, maka pemilik baru berhak atas dividen. Akan tetapi jika pemberitahuan transfer baru diterima tanggal pada atau di atas tanggal 12 Desember 2007, maka pemilik lama berhak atas cek dividen.

c. Tanggal pembayaran dividen Tanggal pembayaran dividen yaitu tanggal pada saat perusahaan benar-benar mengirim cek dividen kepada setiap pemegang saham. Pembayaran dividen dapat digunakan sebagai sinyal bahwa perusahaan telah menunjukkan kinerjanya dengan dengan baik dan penurunan dividen menunjukkan kinerja perusahaan yang buruk. Pada dasarnya, perusahaan cenderung meningkatkan dividen jika terdapat tingkat profitabilitas yang tinggi di masa depan dan menurunkan dividen jika manajemen yakin bahwa tidak terdapat cash flow yang dapat mendukung pembayaran dividen.

\section{Metodologi Penelitian \\ 3.1 Populasi dan Metode Penarikan Sampel}

Dalam penelitian ini populasinya adalah seluruh perusahaan yang terdaftar di Bursa Efek Indonesia dengan kriteria penarikan sampel adalah sebagai berikut:

1. Perusahaan tersebut sudah terdaftar di BEI 
2. Perusahaan tersebut tidak keluar (delisting) dari BEI selama periode.

3. Perusahaan tersebut telah membayar dividen

\subsection{Operasionalisasi Variabel}

Variabel yang diteliti adalah pembagian dividen sebagai variabel bebas dan harga saham sebagai variabel terikat.

\subsubsection{Pembagian dividen}

Data-data yang berkaitan dengan pembagian dividen adalah:

1. Jumlah dividen per lembar yang akan dibagikan

2. Dividen yield

\subsubsection{Harga saham}

Data yang berkaitan dengan harga saham adalah harga pasar saham dalam setahun. Variabel, sub variabel, indikator/ukuran yang diteliti dapat diikhitasarkan pada tabel di bawah:

Tabel 3

Operasionalisasi Variabel

Studi Terhadap Pembagian Dividen dan Dampaknya Terhadap Harga Saham Perusahaan-Perusahaan yang Terdaftar di Bursa Efek Indonesia

\begin{tabular}{|l|l|l|c|l|}
\hline Variabel & Sub Variabel & \multicolumn{1}{|c|}{ Indikator } & Ukuran & \multicolumn{1}{c|}{ Skala } \\
\hline Dividen & Dividen tunai & Dividend per Share & $\frac{\text { Total dividen }}{\text { Jumlah saham beredar }}$ & Rasio \\
\cline { 3 - 5 } & & Dividen Yield & $\frac{\text { Dividen per lembar saham }}{\text { Harga per lembar saham } 100 \%}$ & Rasio \\
\hline Saham & Harga Saham & $\begin{array}{l}\text { Harga saham dalam } \\
\text { setahun }\end{array}$ & Harga pasar saham dalam setahun & \\
\hline
\end{tabular}

\subsection{Metode Pengolahan/Analisis Data}

Metode pengolahan dan analisis data dalam penelitian ini adalah deskriptif dan komparatif. Secara deskriptif, penulis akan mengelompokan dividen sesuai dengan:

1. Besaran pembagian dividen

2. Variabilitas dividen dilihat dari dividen yieldnya.

Analisis komparatif dilakukan dengan membanding pembagian dividen dengan harga saham atau pergerakan harga saham. Data yang telah dikumpulkan mengenai semua variabel penelitian kemudian diolah atau dianalisis dengan menggunakan metode statistik.

\section{Hasil dan Pembahasan}

\subsection{Kinerja Saham Bursa Efek Indonesia \\ 4.1.1. Emiten Saham}

Pada tahun 2014 terdapat 506 emiten yang terdaftar. Jumlah emiten tercatat pada tahun 2012 dan 2013 adalah 459 dan 483 perusahaan.

\subsubsection{Frekuensi, Volume dan Nilai Transaksi Saham}

Walaupun sepanjang tahun 2011 sampai 2014 kondisi perekonomian global dan nasional tidak menunjukan perkembangan yang menggembirakan, minat investor saham di BEI masih mengalami pertumbuhan. Seperti ditunjukan pada Tabel 4, frekuensi transaksi saham masih mengalami pertumbuhan, yaitu sebesar $37,22 \%$. 
Dari sisi volume perdagangan saham, minat investor masih lebih baik dari tahun sebelumnya. Volume transaksi perdangan saham pada tahun 2014 menurun $1,16 \%$. Nilai transaksi saham mengalami penurunan sebesar 4,52\% pada tahun 2014 .

Indikator kinerja bursa efek pada tahun 2011-2014 sebagai berikut :

Tabel 4

Frekuensi, Volume dan Nilai Transaksi saham

\begin{tabular}{|l|c|r|r|r|}
\hline \multicolumn{1}{|c|}{ Tahun } & \multicolumn{1}{c|}{2011} & \multicolumn{1}{c|}{2012} & \multicolumn{1}{c|}{2013} & \multicolumn{1}{c|}{2014} \\
\hline $\begin{array}{l}\text { Frek Transaksi } \\
(\times)\end{array}$ & $28,023,050$ & $29,941,043$ & $37,499,462$ & $51,457,606$ \\
\hline Pertumbuhan & & $6.84 \%$ & $25.24 \%$ & $37.22 \%$ \\
\hline $\begin{array}{l}\text { Vol. Transaksi } \\
\text { (juta lembar) }\end{array}$ & $1,203,550$ & $1,053,762$ & $1,342,657$ & $1,327,016$ \\
\hline Pertumbuhan & & $-12.45 \%$ & $27.42 \%$ & $-1.16 \%$ \\
\hline $\begin{array}{l}\text { Nilai Transaksi } \\
\text { (Rp miliar) }\end{array}$ & $1,223,441$ & $1,116,113$ & $1,522,122$ & $1,453,392$ \\
\hline Pertumbuhan & & $-8.77 \%$ & $36.38 \%$ & $-4.52 \%$ \\
\hline
\end{tabular}

Sumber: IDX statistic

\subsubsection{Indeks Harga Saham dan Kapitalisasi Pasar}

Rata-rata harga pasar saham pada tahun 2014 lebih tinggi dari tahun 2013. Indeks Harga Saham Gabungan naik dari
4.274,18 pada tahun 2013 menjadi 5.226, 95 pada tahun 2014. Akibatnya, kapitalisasi saham yang terdaftar di BEI naik dari Rp 4,22 biliun pada tahun 2013 menjadi Rp 5,23 biliun pada tahun 2014 .

Tabel 5

Kapitalisasi dan Indeks Harga Saham

\begin{tabular}{|l|c|c|r|r|}
\hline \multicolumn{1}{|c|}{ Tahun } & \multicolumn{1}{c|}{2011} & \multicolumn{1}{c|}{2012} & \multicolumn{1}{c|}{2013} & \multicolumn{1}{c|}{2014} \\
\hline Indeks Harga Saham & $3.821,99$ & $4.316,69$ & $4.274,18$ & $5.226,95$ \\
\hline Kapitalisasi Pasar (Rp milyar) & 3.537 .294 & 4.126 .995 & 4.219 .020 & 5.228 .043 \\
\hline
\end{tabular}

Sumber: Bursa Efek Indonesia

\subsection{Pola Pembagian Dividen Tunai \\ 4.2.1. Emiten Pembagi Dividen}

Pada tahun 2014, diantara 506 emiten saham yang terdaftar di BEI hanya 217 emiten atau 53,75\% yang membagikan dividen. Jumlah emiten yang membagikan dividen dari tahun 2011 sampai 2014 selalu menunjukan kenaikan emiten yang membagikan dividen sebanyak 285 emiten yaitu dari 176 perusahaan pada tahun 2011, 189 perusahaan pada tahun 2012 , 208 pada tahun 2013 dan 217 emiten yang membagikan dividen pada tahun 2014.
Bila dilihat rasio antara perusahaan yang membagi dividen dengan perusahaan yang terdaftar di bursa efek, jumlah nya tidak mencapai separuh atau kurang dari $50 \%$. Rasio perusahaan terbuka yang membagi dividen pada tahun 2012 adalah 35,85\%, meningkat menjadi 40,96\% pada tahun 2013 dan sedikit menurun pada tahun 2014 menjadi $40,91 \%$.

\subsubsection{Klasifikasi Dividen Menurut Nilai DPS}


Besaran dividen per lembar yang dibagikan pada tahun 2011-2014 bervariasi dari Rp 0,05 sampai dengan Rp 46.195. Dalam sub-bagian ini penulis mengelompokan dividen berdasarkan jumlah dividen yang dibagikan. Tujuan penulis adalah untuk menunjukan emiten-emiten yang mampu membagi dividen tunai dalam jumlah yang besar. Tentunya hal ini sangat berguna bagi investor yanag berorientasi untuk memperoleh keuntungan yang berasal dari dividen. Berikut pengelompokan dividen berdasarkan jumlah dividen yang dibagikan:

Tabel 6

Klasifikasi Dividen Per Lembar Saham Tahun 2011-2014

(dalam Rupiah)

\begin{tabular}{|c|c|c|c|}
\hline No & Dividen per Lembar & \# Emiten & $\%$ \\
\hline 1 & $>1000$ & 7 & $2.46 \%$ \\
\hline 2 & $500 \mathrm{sd} 999,99$ & 6 & $2.11 \%$ \\
\hline 3 & $100 \mathrm{sd} 499,99$ & 33 & $11.58 \%$ \\
\hline 4 & $50 \mathrm{sd} 99,99$ & 25 & $8.77 \%$ \\
\hline 5 & $10 \mathrm{sd} 49,99$ & 82 & $28.77 \%$ \\
\hline 6 & $<10$ & 132 & $46.32 \%$ \\
\hline Total & & 285 & \\
\hline
\end{tabular}

Sumber: Bursa Efek Indonesia, www.sahamok.com. (Diolah oleh penulis, 2015)

Berdasarkan Tabel 6 tersebut di atas, perusahaan yang mampu membagi dividen diatas Rp 1000 hanya 7 emiten atau 2,46\%. Sebagian besar emiten hanya membagi dividen antara Rp 1050 , yaitu 82 emiten atau $28,77 \%$ dan kurang dari Rp 10 per lembar yaitu 132 emiten atau $46,32 \%$.

Berdasarkan Tabel 6, emiten yang membagikan dividen besar diatas $\mathrm{Rp}$ 1000 per lembarnya adalah Multi Bintang Indonesia Tbk (MLBI), Taisho Pharmaceutical Indonesia Tbk (SQBB), Delta Djakarta Tbk (DLTA), Merck Tbk (MERK), Adira Dinamika Multi Finance Tbk (ADMF), HM Sampoerna Tbk
(HMSP) dan Indo Tambangraya Megah Tbk (ITMG).

\subsubsection{Konsistensi Dalam Membagi Dividen}

Dari 287 perusahaan yang membagi saham selama tahun 20112014 , hanya 122 atau $42,81 \%$ yang rutin membagi dividen setiap tahunnya. Dalam 122 emiten tersebut, termasuk 13 perusahaan yang membagikan dividen diatas Rp 500 per lembarnya.

Daftar frekuensi dan keteraturan dalam membayar dividen terhitung pada akhir tahun 2014 dapat diikhtisarkan sebagai berikut:

Tabel 7

Frekuensi Pembagian Dividen 2011-2014

\begin{tabular}{|c|c|c|}
\hline No & $\begin{array}{c}\text { Frekuensi Pembagian Dividen Selama 4 } \\
\text { Tahun (2011-2014) }\end{array}$ & Jumlah Emiten \\
\hline 1 & Teratur 4 kali & 122 \\
\hline 2 & Teratur 3 kali & 19 \\
\hline 3 & Teratur 2 kali & 29 \\
\hline
\end{tabular}




\begin{tabular}{|c|c|c|}
\hline 4 & Tidak Teratur: $3 \mathrm{kali}$ & 22 \\
\hline 5 & Tidak Teratur: $2 \mathrm{kali}$ & 27 \\
\hline 7 & Tidak Teratur: 1 kali & 66 \\
\hline
\end{tabular}

Sumber: IDX

\subsubsection{Klasifikasi Dividen Menurut Kepemilikan}

Keputusan pembagian dividen dilakukan oleh rapat umum pemegang saham (RUPS). Tentunya pemilik saham mayoritas akan banyak memberikan pengaruh pada putusan pembagian dividen. Berdasarkan 122 emiten yang konsisten membagi dividen, struktur kepemilikan mayoritas perusahaan tersebut dapat disampaikan sebagai berikut:

Tabel 8

Kepemilikan Saham

\begin{tabular}{|c|c|c|c|}
\hline No & Kepemilikan Saham & Jumlah Emiten & $\%$ \\
\hline 1 & Asing & 42 & 34 \\
\hline 2 & Negara & 22 & 18 \\
\hline 3 & Publik & 59 & 48 \\
\hline
\end{tabular}

Sumber: IDX

Berdasarkan Tabel 8, emiten yang kepemilikan sahamnya dimiliki oleh publik paling banyak yaitu 59 emiten atau sebesar $48 \%$. Emiten yang dimiliki oleh asing cukup besar yaitu sebanyak 42 emiten atau sebesar $34 \%$ dan kepemilikan saham negara cukup kecil yaitu sebanyak 22 emiten atau sebesar $18 \%$.

\subsection{Variabilitas Berdasarkan Dividend Yield}

Dividen

Berdasarkan rata-rata harga saham pada saat tutup buku tahunan yang disajikan pada statistik bursa efek, dividend yield perusahaan yang membagikan dividen sangat bervariasi. Dari perusahaan yang konsisten membagikan dividen selama periode 2011-2014, dapat disampaikan sebagai berikut:

1. Dividen yield sampai dengan bervariasi dari $0,02 \%$ sampai dengan $133,33 \%$.

2. Rata-rata dividen yield dari setiap emiten bervariasi dari $0,02 \%$ sampai dengan $73,15 \%$
3. Standar deviasi dividend yield tahun 2012-2014 bervariasi dari 0,00\% sampai dengan $73,15 \%$

4. Coefisien variasi yaitu perimbangan antara standar deviasi dengan rata-rata dividend yield bervariasi dari $4,69 \%$ sampai dengan $143,88 \%$

Bagi investor yang konservatif tentunya akan tertarik pada saham yang memiliki risiko relatif (covariance) yang rendah. Namun bagi investor yang mengutamakan keuntungan akan memilih saham yang memberikan yield tertinggi.

Dari data terlihat yang memiliki rata-rata dividend yield paling besar yaitu SQBB dengan rata-rata dividend yield sebesar 84,16\% namun memiliki standar deviasi paling tinggi yaitu sebesar 73,15\%. Bagi investor yang mengutamakan keuntungan sebaiknya memilih saham SQBB.

Dari 122 emiten, emiten yang memiliki risiko relative (covariance) paling rendah yaitu ASDM dengan covariance sebesar $4,69 \%$ dan emiten yang memiliki covariance paling tinggi 
yaitu MDRN sebesar 143,88\%. Bagi investor yang konservatif sebaiknya memilih saham ASDM dikarenakan memiliki risiko paling rendah diantara 122 emiten lainnya.

\subsection{Korelasi Dividen Tunai Terhadap Harga Saham}

Secara teori, tingkat dividen tunai seharusnya berkorelasi positif terhadap harga saham. Dari populasi 122 emiten yang konsisten membagi dividen dari tahun 2011-2014, berdasarkan tabel dibawah menunjukan bahwa 40,16\% atau 49 dividen emiten berkorelasi diatas 0,75 atau sangat kuat terhadap harga saham dan $35,25 \%$ atau 35 dividen emiten berkorelasi diantara $0-0,74$ atau cukup kuat terhadap harga sahamnya.

Terdapat 3 emiten yang dividennya tidak berkorelasi dengan harga saham. Hal ini disebabkan perusahaan selalu membagi dividen dalam jumlah yang sama atau harga sahamnya selama tahun 2011-2014 stagan.

Emiten yang korelasi dividen terhadap harga sahamnya relatif lemah yaitu antara $-0,74$ sampai 0,00 berjumlah $20,49 \%$ atau 25 emiten, dan hanya emiten atau $1,64 \%$ yang korelasinya sangat rendah.

Rekapitulasi dan rincian korelasi dividen terhadap harga saham dari 122 emiten yang konsisten membagi dividen disajikan pada Tabel 9 sebagai berikut:

Tabel 9

Rekapitulasi Koefisien Korelasi Dividen Terhadap Harga Saham 122 Emiten Yang Konsisten Membagi Dividen, 2011-2014

\begin{tabular}{|c|r|r|}
\hline \multirow{2}{*}{ Koefisien Korelasi } & \multicolumn{2}{|c|}{ Emiten } \\
\cline { 2 - 3 } & Jumlah & $\%$ \\
\hline 0,75 sampai 1.00 & 49 & 40.16 \\
\hline 0,00 sampai 0,74 & 43 & 35.25 \\
\hline Na & 3 & 2.46 \\
\hline 0,00 sampai $-0,74$ & 25 & 20.49 \\
\hline -0,75 sampai -1 & 2 & 1.64 \\
\hline Total & 122 & 100.00 \\
\hline
\end{tabular}

Sumber: IDX

Dari Tabel 9, dapat terlihat emiten yang berkorelasi positif paling tinggi yaitu sebesar $75,41 \%$ (rentang antara 0,00 sampai 1,00). Namun, walaupun emiten yang berkorelasi positif paling tinggi tetap saja tidak semua emiten berkorelasi positif, karena ada pula emiten yang berkorelasi negative yaitu sebesar 22,13\% (rentang antara 0,00 sampai -1,00). Sehingga, dapat disimpulkan pembagian dividen tidak selalu mempengaruhi atau berperan dalam pergerakan harga saham, yang berarti teori kebijakan dividen yang mengatakan bahwa pembagian dividen akan mempengaruhi pergerakan harga saham tidak dapat digeneralisasikan.

\section{Penutup}

5.1. Kesimpulan

1. Pola pembayaran dividen perusahaan yang terdaftar di Bursa Efek Indonesia dari tahun 20112014 berdasarkan dari data yang telah dianalisis sampai tahun 2014 dari 506 emiten yang terdaftar di Bursa Efek Indonesia sebanyak 217 emiten yang membagikan dividen. Berdasarkan data yang telah dianalisis ada 13 emiten yang 
membagikan dividen diatas Rp500 per lembarnya. Emiten yang membagikan dividen paling besar yaitu Multi Bintang Indonesia Tbk (MLBI). Dari 217 emiten yang membagikan dividen sampai tahun 2014 ada 122 emiten yang membagikan dividen rutin selama 4 tahun dan 13 emiten yang membagi dividen diatas Rp500 per lembarnya termasuk kedalamnya. Dari 122 emiten yang membagikan dividen secara rutin, kepemilikan sahamnya paling banyak dimiliki oleh publik yaitu sebanyak 59 emiten atau sebesar 48\%, kepemilikan asing sebnayak 42 emiten atau sebesar 34\% dan yang paling kecil yang dimiliki oleh Negara yaitu sebanyak 22 emiten atau sebesar $18 \%$. Emiten yang membagikan dividen paling besar yaitu Multi Bintang Indonesia Tbk (MLBI) yang pada tahun 2014 membagikan dividen sebesar Rp46.195 dan kepemilikan sahamnya berasal dari asing.

2. Kevariabilitasan dividen berdasarkan dividen yield dari data yang telah diolah, dapat terlihat bahwa Taisho Pharmaceutical Indonesia Tbk (SQBB) yang merupakan emiten terbesar nomer 2 yang memiliki rata-rata dividend yield dan standar deviasinya paling besar. Emiten yang memiliki dividend yield dan standar deviasi paling rendah yaitu Sinar Mas Multiartha Tbk (SMMA). Dari 122 emiten, emiten yang memiliki risiko relative paling tinggi yaitu Modern International Tbk (MDRN) sebesar 143,88\% dan emiten yang memiliki risiko relative paling rendah yaitu Asuransi Dayin Mitra Tbk (ASDM) yaitu sebesar 4,69\%.
3. Konfirmasi korelasi pola pembagian dividen tunai dalam mempengaruhi harga saham yaitu dari data yang telah dianalisis, sebanyak $75,41 \%$ emiten yang berkorelasi positif antara pembagian dividen dan harga saham, yang berkorelasi negatif $22,13 \%$ dan emiten yang tidak berkorelasi sebesar $2,46 \%$. Meskipun emiten yang berkorelasi negatif lebih besar, tidak dapat dikatakan bahwa pola pembagian dividen memiliki peranan dalam mempengaruhi harga saham dikarenakan masih ada emiten yang berkorelasi negatif maupun yang tidak berkorelasi. Maka dapat disimpulkan, pola pembagian dividen tidak selalu mempengaruhi atau berperan dalam pergerakan harga saham, yang berarti teori kebijakan dividen yang mengatakan bahwa pembagian dividen akan mempengaruhi pergerakan harga saham tidak dapat digeneralisasikan.

\subsection{Saran}

1. Bagi Perusahaan

Bagi perusahaan sebaiknya dapat lebih baik menentukan pola kebijakan pembagian dividen, sehingga dapat menarik minat investor untuk menginvestasikan sahamnya.

2. Bagi penulis lain

Dalam pengukuran penelitian ini hanya terbatas pada indikator dan metode analisis tertentu saja. Periode penelitian yang penulis gunakan juga masih terbatas yaitu hanya selama empat tahun periode (2011-2014). Disarankan untuk dilakukan penelitian selanjutnya yang dapat mengurangi keterbatasan penelitian ini, dan mengembangkan penelitian ini 
menjadi lebih baik, dengan menganalisis lebih lanjut harga saham perusahaan-perusahaan dengan metode analisis yang lain, guna mengakurasikan apakah pembagian dividen memiliki pengaruh terhadap harga saham jika dinilai dari berbagai aspek.

3. Bagi Investor dan Calon Investor Bagi investor dalam berinvestasi saham tidak perlu berpatokan kepada pembagian dividen dikarenakan tidak semua perusahaan pembagian dividennya berpengaruh terhadap harga saham. Bagi calon investor yang tetap melihat pembagian dividen untuk menginvestasikan sahamnya sebaiknya bagi investor yang lebih mengutamakan keuntungan besar yang berasal dari dividen disarankan memilih emiten SQBB yang memiliki dividen yield paling besar dan bagi investor yang konservatif sebaiknya memilih saham ASDM dikarenakan memiliki risiko paling rendah dari 122 emiten yang rutin membagikan dividen.

\section{Daftar Pustaka}

Abdul Halim. 2015. Analisis Investasi dan Aplikasinya. Jakarta: Salemba Empat

Agus Harjito dan Martono. 2012. Dasar Dasar Teori Keuangan. Yogyakarta: Ekonisia

Ardiyos. 2010. Kamus Besar Akuntansi. Jakarta: Citra Harta Prima.

Arifin Zaenal. 2005. Teori Keuangan dan Pasar Modal, Yogyakarta: Ekonisia.

Atmaja, L. S. 2008. Teori dan Praktik Manajemen Keuangan. Yogyakarta: Andi.

Darmadji, T., \& Fakhruddin, H. M. 2012. Pasar Modal di Indonesia :
Pendekatan Tanya Jawab. Jakarta: Salemba Empat.

Desmond Wira. 2013. Analisis

Fundamental Saham. Jakarta:

Exceed

Dyah Handayani BS. 2010. Analisis

Faktor-Faktor Yang

Mempengaruhi Dividen Payout

Ratio Pada Perusahaan

Manufaktur Di Bursa Efek

Indonesia Periode 2005-2007.

Skripsi Program Sarjana Ekonomi

Universitas Diponegoro,

Semarang.

F.Syah Mokoadi. 2014. Pengaruh Cash

Position, Profitability, Firm Size,

Potensi Pertumbuhan, Likuiditas

Terhadap Dividend Payout Ratio

Pada Perusahaan Rokok Yang

Terdaftar Di Bei. Skripsi Program

Sarjana Ekonomi Universitas

Bengkulu, Bengkulu.

Hanafi Mamduh M. 2004. Manajemen

Keuangan Yogyakarta: BPFE.

Horngren Charles T. dan Walter T. Harrison Jr. Akuntansi. Edisi 7.

Alih Bahasa: Gina Gania dan

Danti Pujianti. Erlangga, Jakarta.

Irham Fahmi.2013.Pengantar Pasar

Modal. Bandung: Alfabeta

Jogiyanto. 2012. Teori Portofolio dan

Analisis Investasi. Yogyakarta:

BPFE Yogyakarta.

Kamaludin dan Rini Indriani. 2012.

Manajemen Keuangan. Bengkulu:

CV. Mandar Maju.

Kieso, Donald E. Weygandt Jerry J. dan

Terry D. Warfield. 2007.

Akuntansi Intermediate. Alih

Bahasa: Emil Salim. Erlangga,

Jakarta.

Monang Situmorang. 2014. Akuntansi

Keuangan. Bogor: Universitas

Pakuan (Diktat Kuliah)

Sabar Warsini. 2009. Manajemen

Investasi. Jakarta: Semesta Media. 
Suad Husnan 2009. Dasar-dasar Teori Portofolio dan Analisis Sekuritas. Yogyakarta: UPP-AMP YKPN.

Tjiptono Darmadji dan Hendy $M$. Fakhruddin. 2012. Pasar Modal Di Indonesia: Pendekatan Tanya Jawab. Jakarta: Salemba Empat
Van Horne James C. dan Wachowicz, Jr John M. 2013. Prinsip-Prinsip Manajemen Keuangan. Edisi 13. Alih Bahasa: Quratul'ain Mubarakah. Salemba Empat, Jakarta. 